\title{
Economic Prospects as well as Human Rights Violation at Shrimp Farming: A study based in south west coastal region of Bangladesh
}

\author{
Tanvir Alam, Shahi Md. ${ }^{1}$, Shifuzzaman, Lasker ${ }^{2}$ \\ ${ }^{1}$ (Former Student of Economics Discipline, Khulna University, Khulna, Bangladesh) \\ ${ }_{2}^{2}$ (Former Student of Law/Human Rights Law Department, Dhaka International University, Dhaka, Bangladesh)
}

\begin{abstract}
Shrimp is an important export commodity in Bangladesh. The districts in which shrimp cultivation occurred are Bagerhat, Khulna and Satkhira in Khulna Division and Cox's Bazar, Chittagong and Noakhali in Chittagong Division. Out of our total quantity of shrimp exported from the country during 2001 (42000 tonnes), the share of Bagda was 25000 tonnes (58\%) and Golda 12000 tonnes (28\%). Other varieties like Harina amounted to 6000 tonnes (15\%) (Source: Banks' Report). Bangladesh accounts for only $2.5 \%$ of the total world export of shrimp. But in prospective of Bangladesh, Shrimp is the second most important export, employing 840,000 people (Frank Burger, 20002). Frank Burger also states that shrimp represents $90 \%$ of all marine products exported from Bangladesh. But there is mixed image about Bangladeshi shrimp in the international market. In the report published by the Environmental Justice Foundation of London, UK, titled "Smash and Grab: Corruption, conflict and Human Rights Abuse in shrimp Industry" in March 2003, a grey picture of Human Rights situation has been exposed. In our national and local newspapers, news of abuse of Human Rights in the shrimp industry continues to be published regularly. To think that if we keep our eyes closed and believe that no one will know what is happening, and if we do not admit, the occurrences will not be proved, will be a gross mistake instead, we need to be courageous. We must investigate the basic causes behind these occurrences. Coordinated efforts are needed to be undertaken in order to reduce the incidence of such occurrences. We must understand that unless the local marginal landowners, the local workers do not get an equitable share of the income from the shrimp sector, and if opportunities for unethical activities continue to exist in shrimp trading depots and processing factories, then questions will be asked as to how much the common people are benefited by shrimp export?
\end{abstract}

Key Words: Shrimp Farming, Shrimp export, Human Right Violation, Social conflict, Women violence

\section{Introduction}

Shrimp culture is of central importance to the fisheries sector in Bangladesh. It grew from next to nothing in the early 1970s to contribute about $11 \%$ of total exports in the mid-1990s (DOF 1995). No other primary commodity enjoyed such spectacular growth in post-independence Bangladesh. Although shrimp farming has had a significant impact in the economy in Bangladesh, it has had high environmental cost including destruction of mangrove forests, reduction in crop production (especially rice) and green vegetation. It has also set in motion socioeconomic changes (both positively and negatively). The leading shrimp farming areas of Bangladesh are the Bagerhat, Khulna and Satkhira Districts in the south-western region, Cox's Bazar Districts in south-eastern region, and to some extent Pirojpur District in the south-central region. Experts and fisheries resource planners predict that all leading shrimp areas are unlikely to experience similar expansions (MPO 1987).

\subsection{History of Shrimp Farming in Bangladesh}

According the fisheries experts, the history of shrimp cultivation in this country is quite old. Shrimp cultivation started in the Sundarbans region of Bangladesh in 1929-30. Before the implementation of the Coastal Embankment Project, i.e., until the decade of 1950s, polders used to be built on the low lying lands on the bank of rivers to cultivate shrimp. The shrimp were thus produced to consume in the local market. When water-logging became the bane of the lands within the polders of the Coastal Embankment Project and agriculture became impossible as a result of thereof, ghers were built inside the polders for cultivation of fish. Initially, Tengra, Bhetki, Parshya- fish varieties used to be grown in those gheers. It was in the late 1970s, those gheers began to transform themselves into shrimp farms due to the increasing demand and price of shrimp in the international market. 


\subsection{History of Human Rights Violation in Shrimp Farms}

In the beginning, large shrimp farms developed on the initiative by the outsiders and influential people. Influential businessmen from outside developed an entente with the local influential people. They influenced the local administration and with the help of large armies of muscle-men committed various crimes like illegal occupation of land, forcible construction of shrimp polders etc. and earned huge profits. People had launched many movements against this kind of anti-people and environmentally unsound shrimp farming. As a result of widespread people's movement, media campaign etc. the area of shrimp farms in this region became smaller and smaller. Community shrimp farms, cooperative shrimp farms and small individually owned shrimp farms began to e established. Because of weak governance, murder, looting of shrimps, non-payment of lease money, illegal activities conducted through shrimp farm employees, non-payment of wages etc. still continue.

\section{Methodology}

The investigation has been made in Khulna District (considered Thanas are Rampal, Mongla, Koyra, Paikgacha, Dumuria, Batiaghata), Bagerhat District (Moregong Thana) and Satkhira District (Debhata and Shymnagar Thana). The investigation has been effected under the following methodology:

- Reviewing all documents, research reports, government documents etc.

- Reviewing the newspaper (local and national) clipping of the last two years (2010-2011)

- Reviewing the court cases in Satkhira, Khulan and Bagerhat districts especially those related to shrimp issues

- Reviewing the Shalish (mediation) effected during the last two years (2010-2011)

- Examining the answers to the questionnaire

- Discussions with the victims

- Collecting information from government and non-government offices

III.

Findings

After the investigation, we have categorized our findings into two main heads. Those are Economic and Violation of Human Rights.

\subsection{Economic Findings}

Shrimp sector is now moving forward through a series of curves and bends in Bangladesh. It is contributing a vital role in the major economic sides. Like-

- $\quad$ Foreign Earnings- Shrimp, an agricultural product is recognized as a considerable one for its remarkable contribution in soaring the foreign earnings and occupies the $4^{\text {th }}$ position among the export items. Bangladesh has exported 210.28 million pound fish products in the year 2008-2009. It is exporting frozen shrimp to about 30 countries of the world of which USA, Japan, Belgium, UK, The Netherlands, France, Italy, Germany, Canada and South Africa are the most leading buying countries (Shrimp Market Report 2010). During the last 25 years, export earning increased from US\$3.17 million to US\$454.53 million, export generally accounts for $84 \%$ of the export earnings.

- $\quad$ New Industry- During the last 25 years, number of fish processing plant increased from 15 to 90 .

- GDP Growth Rate- It contributes $4.7 \%$ to GDP and about $8 \%$ to total export earnings. At present, in total world shrimp production, $4.21 \%$ is produced in Bangladesh and it is the $7^{\text {th }}$ largest cultured shrimp producer in the world. Thus the shrimp has become a golden fishery resources in Bangladesh.

- Employment Generation- About 1.2 million people directly and 10 million people indirectly associated with this sector.

- Usages of Fallen Lands- A total of about 156945 hectares of land are now under shrimp farming in south-west coastal region. In which Khulna has 51667 hectares, Bagerhat has 59393 hectares, Satkhira has 45885 hectares (EPB 2006).

- $\quad$ Additional Local Business- Shrimp farming also introduced some other additional business like poultry bird farming, feed mills. This additional businesses have generated new income generation sectors.

\subsection{Human Rights Violation Findings}

The shrimp belt of Bangladesh is always the subject of debates on law and order. There have been some incidents of violence in connection with shrimp farming, with the most common incidents involving leased lands. In most cases, outsiders impose force to acquire land and this process also results in increased corruption among the law enforcing agencies. Control of large shrimp gheers by outsiders is the prime cause for social imbalance and deteriorating law and order in rural coastal areas.

- Land Conflict- Shrimp farm related land conflicts are the major problems of this region. Generally land related disputes and violence occur in: 
Economic Prospects as well as Human Rights Violation at Shrimp Farming: A study based in south

$>$ Establishment of large shrimp farm in the face of the unwillingness of the local small landowners and maintaining possession of the same

$>$ Forcible occupation of the comparatively weaker farm owners

$>$ Non-payment of lease money to small landowners and breach of agreement

$>$ Establishing large shrimp farm by illegally leasing khas land that ought to have been leased to the landless

- Violence Against Women- In shrimp farms, women are maltreated in various ways. They are discriminated against in respect of employment and wage rate, sexual harassment and physical violence is also committed against them.

TABLE 1: Dealings with local women

\begin{tabular}{|l|c|c|}
\hline \multirow{2}{*}{ Name of Thana } & \multicolumn{2}{|c|}{ Number of Respondents } \\
\cline { 2 - 3 } & Mistreatment/ Abuse & Others \\
\hline Batiaghata & 1 & 14 \\
\hline Rampal & 10 & 5 \\
\hline Debhata & 9 & 6 \\
\hline Koyra & 6 & 9 \\
\hline Shyamnagar & 9 & 6 \\
\hline Morelgong & 10 & 5 \\
\hline Mongla & 6 & 9 \\
\hline Paikgacha & 12 & 3 \\
\hline Bagerhat & 15 & 0 \\
\hline Dumuria & 6 & 9 \\
\hline
\end{tabular}

\section{Source: Authors' Own Survey}

Harassment of female workers is a regular feature in shrimp related work. Female workers in shrimp farms, depots and processing plants have to endue hazardous working conditions. Gender discrimination in wage rate, indecent remarks, physical torture and verbal abuse are widespread. They often face low prestige in the community as a result of working in shrimp farms.

- Restricting Access to Common Property- Shrimp farming has been criticized for restricting access to common property; it has also been accused of being responsible for depletion of common property resources. Shrimp is farmed by inundating large portions of agricultural lands. Usually divided and fenced into plots. Discussions with local communities have established the fact that shrimp farming has really restricted access to paths and walk ways. Local people also use the embankments constructed in and around the farms for communication. But many areas there are restrictions to their use.

- Blockage of Canals due to Shrimp Farming- Discussing with the local communities have illustrated that shrimp farming has negative impact on management of water bodies and canals. In every group discussion that we conducted, local people said that shrimp farming has created blockage of canals and disputed water management system.

TABLE 2: Blockage of canals due to shrimp farming

\begin{tabular}{|l|c|c|}
\hline \multirow{2}{*}{ Name of Thana } & Blockage of Canals & \\
\cline { 2 - 3 } & Yes & No \\
\hline Batiaghata & 6 & 9 \\
\hline Rampal & 14 & 1 \\
\hline Debhata & 10 & 5 \\
\hline Koyra & 12 & 3 \\
\hline Shyamnagar & 9 & 6 \\
\hline Morelgong & 4 & 11 \\
\hline Mongla & 15 & 0 \\
\hline Paikgacha & 13 & 2 \\
\hline Bagerhat & 5 & 10 \\
\hline Dumuria & 8 & 7 \\
\hline
\end{tabular}

Source: Authors' Own Survey

There are officials rules that no registration be given without ensuring that any farm cannot create any blockage to canals and water bodies. Shrimp farm owners very often disregards these rules.

- Loss of Agricultural Land as Result of Shrimp Farming- Most of the agricultural lands in the Southwest Coastal Region are Tidal Wetlands. By enclosing the area in polders, they were converted into perennial agricultural lands. The polder system is basically dependent upon an efficient drainage system. But 
Economic Prospects as well as Human Rights Violation at Shrimp Farming: A study based in south unplanned shrimp farming has disrupted the drainage system. While on one hand, drainage of surplus rainwater is obstructed, on other hand seepage of saline water from adjacent shrimp farms causes damage of crops.

TABLE 3: Loss of Wetland Area due to Shrimp Farming

\begin{tabular}{|l|c|}
\hline \multicolumn{1}{|c|}{ Name of Thana } & Blockage of Canals \\
\hline Batiaghata & 18 \\
\hline Rampal & 16750 \\
\hline Debhata & 110 \\
\hline Koyra & 217 \\
\hline Shyamnagar & 90 \\
\hline Morelgong & 590 \\
\hline Mongla & 20 \\
\hline Paikgacha & 4440 \\
\hline Khulna & 400 \\
\hline Dumuria & 2238 \\
\hline
\end{tabular}

\section{Source: Authors' Own Survey}

- Labor Rights Condition- Labors are engaged in the shrimp farms in informal manner fully- without any appointment letter or specific job description. They have to perform whatever the owner or manager orders them to do. They do not have any organization or union and no one dears to voice any protest against the powerful shrimp lords.

$>$ Wage rate in shrimp farming related work is not higher than that of non-shrimp work. Our investigation has revealed that wages are even lower and very often jobs are not regular. In Bagerhat, wage in shrimp related work is BDT.70/day for a person and BDT. 65 for non-shrimp work. But in Batiaghata, a worker of nonshrimp work gets BDT. 80/day and BDT. 60 for shrimp related work. But wage rate for female workers is lower than that of their fellow male workers.

$>$ Working hour in shrimp farms per day is more stressful than that of the non-shrimp work. Shrimp farm workers have to work as long as 16 hours and for women it goes as high as 12 hours in depots and processing plants. In peak season, workers have to work all day to harvest shrimp. The idea of weekly holiday is simply absent in shrimp related work, whether in shrimp farms or in depots.

$>$ Shrimp farm workers endure a hazardous working condition. Some of the hazards we have identified are injuries related work, lack of health facility, working in the polluted environmental condition, virus infection, skin disease, overtime work, enduring natural disaster, terrorism, lack of security etc. These conditions prevail almost everywhere.

\section{Conclusion}

In Bangladesh the improvement and exploitation of the potential of the frozen food export including shrimp has been slow. Although there is very profound demand for shrimp in overseas markets. Bangladesh could not make significant breakthrough in the factors related to shrimp export. Shrimp has been identified as an export focal point area in Bangladesh in new export policy. On other hand farm-grabbing by using political influence, looting the shrimp from the farms of the comparatively weaker owners, sexual abuse of women, nonpayment of lease money, irregular payment of wages, long working hours etc. are all causes to disputes and end in conflicts and violence. It is hoped the government would extend all possible cooperation to shrimp producers to successfully address these challenges. In order to expand markets for Bangladesh's shrimp exports, producers, on their part, will have to ensure adherence to international standards, and high quality, particularly with regard of health, environment and labor standards. Also a monthly audit to Human Legal Rights (HLR) in shrimp farming in the south west coastal region will be very effective. Side by side awareness campaign on HLR issue is essential; but it should kept in mind that violation of rights cannot be attributed only to attitudes and behavioral pattern; structural system should be kept in mind.

\section{Acknowledgement}

We are grateful to Mr. Zakir Kabir; Abul Kalam Azad Advocate; Secretary of Satkhira Press Club; Gautam Sarkar Advocate; Habibur Rahman Advocate; Social Activist Anisur Rahim; Editor of Daily Satkhira Chitra; Lecturer Mizanur Rahman Bijoy; Sheikh Abdul Jalil- former Rampal Upazila Chairman; Journalist of National Daily Janakantha at Bagerhat Mr. Babul Sardar; Mr. Atiar Parvez of Daily Prabartan, Khulna; Mr. Kamruzzaman of UNB; Satkhira and different regional and local NGO like CDP, LOCOS, AOSED etc. 


\section{References}

[1] Alauddin, Mohammad. and Hamid, M. Akhter. 2010. Shrimp Culture in Bangladesh with Emphasis on Social and Economic Aspects. Bangladesh Journal of Development Review, 7(1\&2): 82-99

[2] Center for Policy Dialogue. 2010. State of Bangladesh Economy in FY 2009-10: From Stability to Accelerated Growth, Independent Review of Bangladesh's Development (IRBD), p.49

[3] DOF (Department of Fisheries) 1995. Fish Fortnight'95 (leaflet). Dhaka, DOF.

[4] EPB, 2006. Bangladesh Export Statistics, Export Promotion Bureau, Ministry of Commerce, Government of the Peoples Republic of Bangladesh, Dhaka.

[5] EPBB (Export Promotion Bureau, Bangladesh) 1995. Exports from Bangladesh 1972-2 to 2008-9. Dhaka, Export Promotion Bureau, Bangladesh

[6] ESCAP (Economic and Social Commission for Asia and the Pacific) 1988. Coastal environmental management plan for Bangladesh, Volumn II. Final report. Bangkok, United Nations Economic and Social Commission for Asia and Pacific.

[7] Hossain, M.Z. and Islam, S.M.N. 1999. Export Marketing of Shrimp from Bangladesh: A study on Performance and Prospect. Bangladesh Journal of Development Review, 9(1\&2): 81-101

[8] MPO (Master Plan Organization) 1987. Coastal shrimp aquaculture resources, Technical Report No. 18. Dhaka, Master Plan Organization

[9] MarketAsia.1995.U.S.MarketforFrozenShrimpGrowsRapidly,2(2), http://www.milcom.com/rap/v22/shrim-phtml

[10] Sabur, S.A., Palash, M.S., Awal, M.A. and Rahman, K.T. 2010. Shrimp Export from Bangladesh: Effect of war and trade liberation. J. Bangladesh Agril. Univ. 8(1): 127-132

[11] Shrimp Market Report. 2010. www.vietfish.com/En/detail.php?id=9\&artitle=2470, Accessed date: July 10,2012 